\title{
AUDIT MANAJEMEN ATAS FUNGSI PRODUKSI \\ PADA PTP. NUSANTARA VI KAYU ARO KERINCI, JAMBI
}

Oleh:

\author{
Rr. Indah Mustikawati ${ }^{1}$ \\ Randi Maipan ${ }^{2}$ \\ i_mustikawati@uny.ac.id \\ randi.maipan@yahoo.com
}

FAKULTAS EKONOMI

UNIVERSITAS NEGERI YOGYAKARTA

ABSTRAK

\begin{abstract}
Penelitian ini bertujuan untuk mengetahui: 1) Aktivitas atas fungsi poduksi pada PTP. Nusantara VI Kayu Aro, 2) Efektivitas fungsi produksi pada PTP. Nusantara VI Kayu Aro, dan 3) Memberikan saran atau rekomendasi untuk peningkatan efektivitas fungsi produksi pada PTP. Nusantara VI Kayu Aro di masa yang akan datang. Penelitian ini bersifat deskriptif kualitatif yaitu penelitian yang membuat analisis sistem, faktual, dan akurat mengenai fakta-fakta dan sifat-sifat populasi atau daerah tertentu. Metode pengumpulan data pada penelitian ini adalah wawancara, dokumentasi, dan observasi. Teknik analisis data yang digunakan adalah deskriptif kualitatif, yaitu analisis data dengan cara membandingkan antara teori dengan kenyataan yang ada pada perusahaan. Analisis data yaitu Kondisi, Kriteria, Penyebab, dan Akibat.Hasil penelitian ini adalah: 1) Aktivitas fungsi produksi mulai dari jadwal induk produksi, perolehan bahan baku, tingkat produk cacat, perawatan peralatan
\end{abstract}

dan fasilitas produksi, pengembangan angkatan kerja, pengendalian kualitas, dan aktivitas pengepakan dan penyimpanan produk jadi secara umum telah dilaksanakan dengan baik, 2) Secara umum aktivitas fungsi produksi telah efektif namun demikian masih terdapat beberapa permasalahan pada aktivitas jadwal induk produksi dan aktivitas perolehan bahan baku yang disebabkan oleh ketidaktercapaian perolehan bahan baku, 3) Adapun saran atau rekomendasi yang diberikan adalah pertimbangkan dengan matang atas kebijakan replanting dan pemangkasan dengan meminta pertimbangan dari para ahli pertanian yang ada di perusahaan. Selain itu, pencapaian positif yang dicapai perusahaan harus dipertahankan dan ditingkatkan.

Kata Kunci: Audit Manajemen, Fungsi Produksi, PTP. Nusantara VI Kayu Aro Kerinci 


\section{Jurnal Nominal / Volume I Nomor I / Tahun 2012}

\section{A. Pendahuluan}

Perkembangan zaman yang pesat membuat dunia persaingan bisnis semakin hari semakin ketat. Keadaan ini kian menjadi ancaman yang berisiko bagi setiap perusahaan yang ikut serta di dalamnya, dibutuhkan cara dan kemampuan khusus agar perusahaan mampu bertahan dan berhasil memenangi persaingan. Kemampuan perusahaan dalam berinovasi, menerapkan efektivitas, dan efisiensi dalam proses produksinya menjadi salah satu cara bagi perusahaan untuk bisa memperoleh konsumen sebanyak-banyaknya, meningkatkan profitabilitas, dan memenangi persaingan yang ada.

Upaya meningkatkan profitabilitas dan memenangi persaingan tak lepas dari dukungan sebuah fungsi yang penting dalam perusahaan, yaitu fungsi produksi. Fungsi produksi dalam sebuah perusahaan tidak hanya terbatas pada fungsi dasarnya, berupa menambah atau menciptakan kegunaan nilai tambah dan memanfaatkan sumberdaya yang ada dan tersedia. Namun, secara umum berfungsi untuk mentransformasikan input menjadi output dengan ketetapan kualitas yang telah ditetapkan oleh pihak manajemen perusahaan.

Penetapan standar dan target produksi dalam suatu perusahaan sangat diperlukan sebagai pembanding dengan hasil akhir yang diperoleh. Oleh karena itu, dalam proses produksi diperlukan kegiatan evaluasi dengan mencocokkan target awal dengan hasil akhir. Kegiatan ini dinamakan dengan audit operasional.

Audit produksi dan operasional adalah suatu penilaian secara komprehensif terhadap keseluruhan fungsi produksi dan operasi untuk menentukan apakah fungsi ini telah berjalan dengan memuaskan (ekonomis, efisien, dan efektif) (Bayangkara, 2008:107). Audit ini dilakukan tidak hanya terbatas pada unit produksi tetapi juga berlaku untuk keseluruhan proses produksi. Untuk mengidentifikasi dan mengetahui kekurangan, kelemahan, dan tindakan apa yang sebaiknya dilakukan atas temuan dari proses produksi yang dilaksanakan, maka diperlukan audit manajemen.

Audit manajemen bertujuan untuk mengidentifikasi kegiatan, program, dan aktivitas yang masih memerlukan perbaikan, sehingga dengan rekomendasi yang diberikan nantinya akan dicapai perbaikan atas pengelolaan berbagai program dan aktivitas pada perusahaan tersebut. Audit manajemen adalah audit yang dilaksanakan untuk menilai efisiensi dan efektifitas kegiatan suatu organisasi dalam prosesnya untuk mencapai tujuan organisasi yang digunakan untuk mencapai tujuan yang telah ditetapkan (Bayangkara, 2008:2).

Masalah umum sebuah perusahaan dalam pengelolaan proses produksinya adalah rendahnya tingkat pengawasan fungsi produksi dan rendahnya pengawasan atas standar dan target yang ditetapkan, sehingga proses produksi tidak berjalan dengan maksimal dan target awal yang ditetapkan perusahaan tidak dapat tercapai dengan baik.

Pada penelitian ini, audit manajemen atau dikenal dengan istilah pemeriksaan manajemen difokuskan pada fungsi produksi di PTP. Nusantara VI unit Kayu Aro Kerinci atau yang dikenal dengan istilah PTPN VI Kayu Aro Kerinci dan selanjutnya disebut PTP. Nusantara VI Kayu Aro yang kegiatannya adalah memproduksi teh basah menjadi teh kering jenis teh hitam Ortodox dan CTC. PTP. Nusantara VI adalah sebuah Badan Usaha Milik Negara (BUMN) yang bergerak dalam pengolahan hasil perkebunan berupa kelapa sawit, karet, dan teh. PTP. Nusantara VI terbagi atas beberapa unit usaha yang tersebar di beberapa wila- 


\section{Jurnal Nominal / Volume I Nomor I / Tahun 2012}

yah di Provinsi Jambi dan Sumatera Barat. Di Provinsi Jambi, PTP. Nusantara VI tersebar di beberapa wilayah diantaranya di Batang Hari, Bunut, Durian Luncuk, Pinang Tinggi, Rimbo Bujang, Tanjung Lebar, dan Kayu Aro Kerinci, sedangkan di Provinsi Sumatera Barat unit usaha PTP. Nusantara VI tersebar di beberapa wilayah yaitu, Ophir, Pangkalan Lima Puluh Kota, Solok Selatan dan Danau Kembar. PTP. Nusantara VI Kayu Aro mempunyai target produksi tahunan, hal ini dilakukan untuk mengukur tingkat keberhasilan pencapaian produksi di akhir tahun bersangkutan. Namun, dalam pelaksanaannya terjadi ketidaksesuaian antara target yang ditetapkan dengan hasil akhir yang didapatkan. Pada tahun 2011 target produksi teh basah yang ditetapkan adalah sebesar 25.750.000 kg namun, pencapaian di akhir tahun hanya sebesar $18.893 .836 \mathrm{~kg}$. Pada tahun 2010 target produksi teh basah adalah sebesar 25.911.000 kg namun, pencapaian diakhir tahun hanya sebesar 23.871.210 kg. Produksi teh basah pada tahun 2011 sebesar $18.893 .836 \mathrm{~kg}$ mengalami penurunan dibandingkan dengan produksi pada tahun 2010 yaitu sebesar $23.871 .210 \mathrm{~kg}$. Kesenjangan target dengan pencapaian dalam proses produksi di PTP. Nusantara VI Kayu Aro menimbulkan masalah berupa tidak tercapainya target produksi yang telah direncanakan sehingga produksi teh kering mengalami penurunan. Ketidaktercapaian target bahan baku juga menyebabkan mesin produksi bekerja di bawah standar kerja maksimum. Masalah lain yang ditimbulkan adalah biaya perawatan peralatan dan fasilitas produksi yang tidak sebanding dengan waktu kinerja mesin. Agar target produksi dapat dicapai dan penyebab kegagalan dalam mencapai target produksi dapat diketahui, maka pihak manajemen fungsi produksi memerlukan suatu alat ban- tu yaitu audit manajemen atas fungsi produksi.

Mengingat besarnya pengaruh audit produksi dalam meningkatkan pencapaian target produksi perusahaan, maka penerapan audit produksi harus dilakukan dengan tepat sesuai dengan standar dan norma yang berlaku. Berkaitan dengan penjabaran dan pemikiran di atas, maka penulis menetapkan judul "AUDIT MANAJEMEN ATAS FUNGSI PRODUKSI PADA PTP. NUSANTARA VI KAYU ARO KERINCI, JAMBI”.

Tujuan penelitian ini adalah: (1) Untuk mengetahui aktivitas fungsi produksi di PTP. Nusantara VI Kayu Aro, (2) Untuk mengetahui efektivitas aktivitas fungsi produksi di PTP. Nusantara VI Kayu Aro, (3) Untuk memberikan saran atau rekomendasi yang dapat diberikan atas berbagai kelemahan yang ditemukan. Hasil penelitian ini diharapkan dapat memberikan masukan bagi dunia akademis bidang audit manajemen dan dapat digunakan sebagai bahan pertimbangan kebijakan manajemen atas fungsi produksi pada PTP. Nusantara VI Kayu Aro untuk perbaikan dimasa yang akan datang.

\section{Auditing}

Audit adalah suatu proses sistematik dan objektif dari penyediaan dan evaluasi bukti-bukti yang berkenaan dengan pernyataan (assertion) tentang kegiatan dan kejadian ekonomi guna memastikan derajat atau tingkat hubungan antara pernyataan tersebut dengan kriteria yang ada serta mengkomunikasikan hasil yang diperoleh tersebut kepada pihak-pihak yang berkepentingan (Indra Bastian, 2007:2-3)

Pengauditan adalah suatu proses sistematis untuk mendapatkan dan mengevaluasi bukti yang berhubungan dengan asersi tetang tindakan-tindakan dan 


\section{Jurnal Nominal / Volume I Nomor I / Tahun 2012}

kejadian-kejadian ekonomi secara objektif untuk menentukan tingkat kesesuaian antara asersi tersebut dengan kriteria yang telah ditetapkan dan mengkomunikasikan hasilnya kepada pihak-pihak yang berkepentingan (Haryono Yusuf, 2001:11).

Menurut The Report of the Committee on Basic Auditing Concepts the American Accounting Association, auditing adalah:

A systematic process of objectively obtaining and evaluating ovidence regarding assertion about economic actions and events to ascertain the degree of correspondence between those assertions and established criteria and communicating the results to interested users (Boyton dan Johnson, 2006:6).

Menurut Arens dan Loebbecke auditing adalah: proses yang ditempuh oleh seseorang yang kompeten dan independen agar dapat menghimpun dan mengevaluasi bukti-bukti mengenai informasi yang terukur dari suatu entitas (satuan) usaha untuk mempertimbangkan dan melaporkan tingkat kesesuaian dari informasi yang terukur tersebut dengan kriteria yang telah ditetapkan (Arens dan Loebbecke, 1998:1).

ASOBAC (A Statement of Basic Auditing Concepst) medifinisikan auditing sebagai:

Suatu proses sistematis untuk menghimpun dan mengevaluasi bukti-bukti secara objektif mengenai asersi-asersi tentang berbagai tindakan dan kejadian ekonomi untuk menentukan tingkat kesesuaian antara asersi-asersi tersebut dengan kriteria yang telah ditentukan dan menyampaikan hasilnya kepada para pemakai yang berkepentingan (ASOBAC dalam Abdul Halim, 2003:1).

Berdasarkan beberapa pengertian tentang audit yang berasal dari berbagai sumber, dapat disimpul- kan bahwa audit adalah suatu proses sistematis pengevaluasian terhadap bukti-bukti dan tindakan ekonomi yang dilakukan oleh pihak independen untuk memastikan kesesuaian antara kriteria yang telah ditetapkan dengan realita dan kenyataan di lapangan untuk kemudian dikomunikasikan kepada pihak-pihak yang berkepentingan.

\section{Audit Manajemen}

Audit manajemen (management audit) adalah pengevaluasian terhadap efisiensi dan efektivitas operasi perusahaan (Bayangkara, 2008:2).

Audit manajemen adalah pengkajian (review) atas setiap bagian dari prosedur dan metode yang diterapkan suatu organisasi dengan tujuan untuk mengevaluasi efisiensi dan efektivitas. Hasil rekomendasi suatu audit manajemen biasanya berupa rekomendasi kepada manajemen untuk perbaikan operasi (Haryono Yusuf, 2001:16).

Alejendro P. Gorospel (2000) memberikan definisi tentang audit manajemen :

Audit manajemen adalah suatu teknik yang secara teratur dan sistematis digunakan untuk menilai efektivitas unit atau pekerjaan dibandingkan dengan standar-standar perusahaan dan industri, dengan mengunakan petugas yang bukan ahli dalam lingkup objek yang dianalisis, untuk meyakinkan manajemen bahwa tujuannya dilaksanakan, dan keadaan yang membutuhkan perbaikan ditemukan (Alejendro P Gorospel dalam Amin Widjaya Tunggal, 2000:2).

Menurut Allan J. Sayle:

"Manajemen audit adalah pengujian yang independen atas bukti yang objektif, yang dilakukan oleh para personil yang kompeten" (Allan J. Sayle dalam Amin Widjaya Tunggal, 2000:3).

Berdasarkan publikasi Institute of Internal Au- 


\section{Jurnal Nominal / Volume I Nomor I / Tahun 2012}

ditor (IAA), audit operasional atau audit manajemen didefinisikan sebagai berikut:

Operational Auditing adalah suatu proses yang sistematis dari penilaian efektivitas, efisiensi, dan ekonomisasi operasi suatu organisasi yang dibawah pengendalian manajemen dan melaporkan kepada orang yang tepat hasil penilaian beserta rekomendasi untuk perbaikan (IIA dalam Amin Widjaya Tunggal, 2000:4).

Berdasarkan beberapa definisi di atas dapat disimpulkan bahwa audit manajemen adalah audit yang dilakukan untuk pengevaluasian terhadap efisiensi dan efektivitas dari operasi yang dilaksanakan oleh suatu perusahaan, melaporkan hasil dari penilaian yang dilakukan dan memberikan rekomendasi untuk perbaikan apabila ditemukan berbagai kelemahan dan kekurangan dalam pengelolaan perusahaan.

\section{Fungsi Produksi}

Untuk menghasilkan barang dan jasa, semua organisasi menjalankan tiga fungsi. Fungsi-fungsi ini merupakan hal yang penting, bukan hanya untuk proses produksi, tetapi juga demi kelangsungan hidup sebuah organisasi. Fungsi-fungsi ini adalah: 1) Pemasaran, yang menghasilkan permintaan, atau paling tidak menerima pemesanan untuk sebuah barang atau jasa (tidak ada aktivitas yang tidak ada penjualan), 2) Produksi/Operasi, yang menghasilkan produk, 3) Keuangan/Akuntansi, yang mengawasi sehat atau tidaknya sebuah organisasi, membayar tagihan, dan mengumpulkan uang (Heizer dan Render, 2006:5).

Aktivitas produksi sebagai suatu bagian dari fungsi organisasi perusahaan bertanggung jawab terhadap pengolahan bahan baku menjadi produksi jadi yang dapat dijual. Untuk melaksanakan fungsi produksi tersebut, diperlukan rangkaian kegiatan yang akan membentuk suatu sistem produksi.

\section{Audit Manajemen Fungsi Produksi dan Operasi}

Audit produksi dan operasi melakukan penilaian secara komprehensif keseluruhan fungsi produksi dan operasi untuk menentukan apakah fungsi ini telah berjalan dengan memuaskan (ekonomis, efektif, dan efisien). Audit ini dilakukan tidak hanya terbatas pada unit produksi tetapi juga berlaku untuk keseluruhan proses produksi dan operasi. Audit ini juga berperan melengkapi fungsi pengendalian kualitas.

Beberapa alasan yang mendasari perlu dilakukannya audit ini, antara lain: 1) Proses produksi dan operasi harus berjalan sesuai dengan prosedur yang telah ditetapkan, 2) Kekurangan atau kelemahan yang terjadi harus ditemukan sehingga dapat diperbaiki, 3) Konsistensi berjalannya proses harus diungkapkan, 4) Pendekatan proaktif harus menjadi dasar dalam peningkatan proses, 5) Berjalannya tindakan korektif harus mendapat dorongan dan dukungan dari berbagai pihak yang terkait (Bayangkara, 2008:177).

\section{B. Metodologi Penelitian}

Penelitian ini merupakan penelitian yang menggunakan metode Ex Post Facto yaitu penelitian yang dilakukan untuk meneliti peristiwa yang telah terjadi kemudian merunut kebelakang untuk mengetahui faktor-faktor yang dapat menimbulkan kejadian tersebut (Sugiyono, 2001:7). Penelitian ini dilakukan untuk meneliti kejadian yang telah terjadi di fungsi produksi pada PTP. Nusantara VI Kayu Aro dan menemukan penyebab kejadian tersebut. Penelitian ini juga termasuk da- 


\section{Jurnal Nominal / Volume I Nomor I / Tahun 2012}

lam penelitian deskriptif kualitatif. Penelitian ini menjelaskan gambaran secara fakta dan aktual terhadap fenomena yang diteliti yaitu bidang audit manajemen yang difokuskan pada penerapan penilaian kinerja pada fungsi produksi.

Rancangan penelitian yang digunakan adalah penelitian studi kasus dikarenakan menggunakan data perusahaan periode yang telah lalu dengan memusatkan objek penelitian tertentu yaitu audit manajemen atas fungsi produksi, penelitian ini dilakukan melalui beberapa tahapan, yaitu:

\section{Tahap survey pendahuluan (preliminary sur- vey)}

Pada tahap ini peneliti melakukan observasi diPTP. Nusantara VI Kayu Aro, melakukan wawancara mengenai hal-hal yang berkaitan dengan organisasi yaitu mulai dari profil organisasi perusahaan, visi dan misi perusahaan, struktur organisasi, lokasi dan kebijakan organisasi, dan hal-hal yang berkaitan dengan aktivitas yaitu pelaksanaan aktivitas produksi.

\section{Tahap Review}

Pada tahap ini peneliti melakukan review apakah sistem pegendalian yang dimiliki PTP. Nusantara VI Kayu Aro menjadi pedoman yang digunakan oleh para pimpinan dan karyawan bagian produksi dalam mengendalikan proses yang berjalan agar tidak keluar dari ketentuan dan standar yang telah ditetapkan.

\section{Tahap Audit Terinci}

Pada tahap ini peneliti menetapkan tiga elemen pokok untuk menguji apakah pengendalian manajemen telah sesuai dengan tujuan perusahaan atau belum. Tiga elemen pokok tersebut adalah:

\section{a. Criteria}

Standar atau norma yang menjadi pedoman bagaimana seharusnya pihak-pihak dalam perusahaan melakukan aktivitasnya sebagai pertanggung jawaban atas wewenang yang dilimpahkan dan menjadi tolok ukur kinerja perusahaan,sehingga dengan adanya criteria dapat ditentukan apakah suatu kondisi menyimpang atau tidak atau apakah sudah sesuai dengan standar apa tidak.

\section{b. Causes}

Causes atau penyebab merupakan seluruh tindakan manajerial ataupun operasional dari pengelola organisasi yang menimbulkan terjadinya penyimpangan antara rencana dengan realisasi. Semua aktivitas atau tindakan tersebut akan diperbandingkan dengan criteria sehingga dapat diketahui apakah criteria yang ada telah tercapai atau dijalankan apa belum. Causes juga termasuk suatu kondisi yang tidak melakukan suatu tindakan yang seharusnya dilakukan (menyimpang dari criteria).

\section{c. Effect}

Effect merupakandampak yang timbul akibat dilaksanakannya causes yang juga hasil perbandingan antara criteria dan causes. Effect dapat bersifat positif dan negatif. Effect positif yaitu akibat yang bersifat ekonomis, efisien, dan efektif, sedangkan effect negatif yaitu akibat yang bersifat tidak efisien(inefficient), tidak efektif(ineffective) dan tidak ekonomis.

\section{Tahap Pelaporan}

Pada tahap ini peneliti menyimpulkan hasil penelitian berdasarkan hasil analisis atas kriteria, sebab, dan akibat pada aktivitas fungsi produksi, kemudian memberikan saran serta rekomendasi perbaikan guna peningkatan efektivitas fungsi produksi dimasa yang akan datang. 


\section{Jurnal Nominal / Volume I Nomor I / Tahun 2012}

\section{Tahap Tindak Lanjut/Rekomendasi}

Pada tahap ini, auditor tidak mempunyai andil. Segala keputusan berada di tangan manajemen PTP. Nusantara VI Kayu Aro, apakah akan mengimplementasikan rekomendasi yang telah ada atau mengabaikan rekomendasi yang diberikan atas kelemahan yang ditemukan.

Subjek dalam penelitian ini adalah kepala pabrik, asisten kepala pabrik, mandor pabrik, dan karyawan bagian produksi di PTP. Nusantara VI Kayu Aro. Objek penelitian adalah lingkungan produksi, strategi produksi, organisasi produksi, sistem produksi serta catatan dan dokumen yang berhubungan dengan fungsi produksi PTP. Nusantara VI Kayu Aro.

Metode pengumpulan data yang digunakan dalam penelitian Audit Manajemen atas Fungsi Produksi di PTP. Nusantara VI Kayu Aro adalah:

\section{Wawancara (Interview)}

Wawancara adalah sebuah metode pengumpulan data dengan proses tanya jawab langsung kepada narasumber untuk mendapatkan data-data atau keterangan mengenai objek yang diteliti, dalam hal ini data yang ingin diperoleh atau dikumpulkan adalah data-data internal perusahaan.

\section{Dokumentasi}

Metode ini dilakukan dengan cara memperoleh atau mendapatkan data-data perusahaan berupa dokumen-dokumen, laporan-laporan, catatan-catatan yang terdapat diperusahaan, struktur organisasi dan lainnya khususnya dokumendokumen atau data terkait fungsi produksi.

\section{Observasi}

Metode observasi adalah metode pengumpulan data dengan cara mendatangi langsung objek yang diteliti sehingga diperoleh gambaran dan in- formasi yang jelas bagaimana keadaan perusahaan sebenarnya dan masalah apa saja yang dihadapi perusahaan.

Teknik analisis data yang digunakan dalam penelitian ini adalah menggunakan metode analisis deskriptif kualitatif. Analisis deskriptif kualitatif adalah analisis data dengan cara mengumpulkan dan menjelaskan data non angka (kualitatif), yang kemudian dibandingkan dengan teori yang bersangkutan untuk memperoleh kejelasan hasil yang dijadikan sebagai kesimpulan dan saran.

\section{Pembahasan dan Hasil}

Laporan Audit Manajemen Atas Fungsi Produksi pada PTP. Nusantara VI Kayu Aro Kerinci, Jambi periode Februari-Maret 2012 adalah sebagai berikut:

\section{Jadwal Induk Produksi}

\section{a. Kondisi (Condition)}

Jadwal induk produksi di PTP. Nusantara VI Kayu Aro Kerinci telah berjalan dan dilaksanakan dengan baik. Unit bisnis mulai dari pemetikan bahan baku (pucuk teh) di lapangan/kebun, pengiriman bahan baku ke pabrik, perawatan dan penggunaan peralatan telah terintegrasi dengan baik. Jadwal produksi di seluruh unit bisnis telah terdokumentasi secara tertulis dan pelaksanaannya telah sesuai dengan ketentuan yang ada. Namun, terdapat permasalahan di bagian peralatan dan fasilitas produksi. Kemampuan maksimal peralatan dan fasilitas produksi mengolah bahan baku menjadi teh kering di tahun 2011 sebesar 25.750 .000 $\mathrm{kg}$ hanya terealisasi sebesar $18.893 .836 \mathrm{~kg}$. Biaya perawatan peralatan dan fasilitas produksi tetap sama walaupun kapasitas produksinya jauh di 


\section{Jurnal Nominal / Volume I Nomor I / Tahun 2012}

bawah target yang ditetapkan.

\section{b. Kriteria (Criteria)}

Jadwal jam kerja bagian pengolahan. Jam kerja bagian pengolahan dilakukan Selasa sampai Minggu. Jam kerja bagian pengolahan dimulai dari jam 7 pagi hingga jam 11 malam. Hari Senin di tiap minggunya tidak ada kegiatan pengolahan/ produksi dikarenakan tidak ada kegiatan pemetikan pucuk teh di hari Minggu (libur). Jadwal jam kerja bagian pengolahan ada di lampiran.

\section{c. Penyebab (Causes)}

Penyebab terjadinya permasalahan di bagian pengolahan di PTP. Nusantara VI adalah ketidakmampuan perusahaan dalam mencukupi kebutuhan bahan baku maksimal yang bisa diproduksi oleh bagian pengolahan. Terbatasnya ketersediaan bahan baku di PTP. Nusantara VI Kayu Aro disebabkan oleh beberapa faktor seperti replanting, pemangkasan, pengaruh cuaca dan hama, dan usia teh yang sudah sangat tua dan kurang produktif dalam menghasilkan bahan baku.

\section{d. Akibat (Effect)}

Peralatan dan fasilitas produksi yang tidak berproduksi secara maksimal menyebabkan peralatan banyak menganggur namun demikian biaya yang dikeluarkan untuk perawatan peralatan dan fasilitas produksi tetap sama sehingga bisa menyebabkan penurunan keuntungan perusahaan.

\section{Aktivitas Perolehan Bahan Baku}

\section{a) Kondisi (Condition)}

Aktivitas perolehan bahan baku berupa pucuk teh basah di PTP. Nusantara VI Kayu Aro telah berjalan dengan baik. Semua ketentuan yang berkaitan dengan aktivitas perolehan bahan baku mulai dari jadwal pemetikan pucuk teh di lapangan, jadwal pengiriman bahan baku ke pabrik, ba- sis borongan, target bahan baku yang harus diperoleh karyawan, harga premi kelebihan target petik, spesifikasi bahan baku, dan dispensasi yang diberikan kepada karyawan tertentu telah terdokumentasi dengan baik di dalam surat edaran yang dikeluarkan oleh direksi. Namun, perusahaan mengalami permasalahan untuk memenuhi target bahan baku yang telah direncanakan. Perolehan bahan baku teh di akhir tahun jauh di bawah target yang ditetapkan sehingga, berdampak pada penurunan produksi teh kering (Ortodox dan CTC).

\section{b) Kriteria (Criteria)}

1) Standard Operational Procedure (SOP). SOP terlampir di lampiran.

2) Surat Edaran No.06.07/3E/08/2010. Surat edaran ini merupakan penyempurnaan dari standar aktivitas perolehan bahan baku sebelumnya. Surat ini berisikan semua kebijakan dan standar perolehan bahan baku. Kebijakan perolehan bahan baku ditetapkan perusahaan bagi setiap pekerja pemetik yang diatur berdasarkan jenis, kualitas pucuk teh dan cara petik yang dilakukan. Pemetikan manual dengan tangan ditetapkan sebesar $37 \mathrm{~kg} /$ orang, pemetikan menggunakan gunting sebesar 47 $\mathrm{kg}$ /orang, dan pemetikan menggunakan mesin sebesar 200 kg/orang. Surat edaran terlampir di lampiran.

\section{c) Penyebab (Causes)}

Kelancaran perolehan bahan baku merupakan tonggak bagi perusahaan untuk bisa melakukan proses produksi dengan baik, sehingga target produksi yang ditetapkan perusahaan dapat tercapai dengan baik. Sebaliknya, apabila bahan baku tidak terpenuhi sesuai dengan target yang ditetapkan 
Jurnal Nominal / Volume I Nomor I / Tahun 2012

maka kuantitas produk akhir akan mengalami penurunan, sehingga pendapatan perusahaan juga akan menurun dan bisa menyebabkan kerugian. Dalam dekade terakhir terjadi ketidaktercapaian target perolehan bahan baku di PTP. Nusantara VI Kayu Aro yang disebabkan hal-hal sebagai berikut:

\section{1) Replanting}

Replanting atau dikenal dengan istilah penanaman ulang lahan lama dengan tanaman baru adalah salah satu langkah yang dilakukan oleh perusahaan untuk meningkatkan perolahan bahan baku namun, dalam pelaksanaanya, cara ini membutuhkan waktu yang lama, durasi pembibitan sampai panen perdana membutuhkan waktu selama empat tahun yang selama periode itu bahan baku tidak dihasilkan dari lahan tersebut.

\section{2) Pemangkasan}

Pemangkasan adalah cara yang dilakukan perusahaan untuk memunculkan tunas muda yang lebih bagus dengan memangkas tanaman lama yang sudah kurang produktif dalam menghasilkan pucuk teh. Durasi pemangkasan sampai bisa dipetik ulang membutuhkan waktu selama tiga bulan yang artinya tanaman yang dipangkas tidak menghasilkan pucuk teh selama masa pertumbuhan tersebut sehingga, produksi bahan baku mengalami penurunan.

\section{3) Pengaruh Cuaca dan Hama Tanaman}

Penurunan kuantitas bahan baku juga di sebabkan oleh pengaruh cuaca dan gangguan hama tanaman teh. Curah hujan yang tinggi menyebabkan pucuk teh yang muncul sedikit. Selain itu, gangguan hama tanaman teh juga menyebabkan banyak pucuk teh yang rusak dan tidak dapat digunakan sebagai bahan baku.

\section{4) Usia Tanaman}

Usia tanaman yang sudah sangat tua juga menjadi salah satu penyebab penurunan kuantitas bahan baku. Tanaman yang ditanam sejak tahun 1929 tidak berproduksi secara efektif lagi.

\section{d. Akibat (Effect)}

Ketersediaan bahan baku dalam proses produksi menjadi suatu keharusan yang bertujuan untuk menghasilkan produk akhir sesuai dengan target yang telah ditetapkan. Apabila bahan baku tidak terpenuhi, maka secara otomatis jumlah produk akhir yang diperoleh akan menurun dari target awal. Langkah yang dilakukan oleh PTP. Nusantara VI Kayu Aro seperti replanting dan pemangkasan menyebabkan pohon teh tidak dapat berproduksi dalam rentang waktu yang lama, sehingga perolehan bahan baku akan menurun. Ancaman alami seperti pengaruh cuaca, hama tanaman, dan usia tanaman juga menyebabkan tanaman teh tidak dapat berproduksi secara maksimal yang pada akhirnya akan menurunkan perolehan bahan baku, sehingga produksi teh jadi (Ortodox dan CTC) tidak sesuai dengan target yang direncanakan.

\section{Aktivitas Perolehan Bahan Baku}

\section{a) Kondisi (Condition)}

Aktivitas perolehan bahan baku berupa pucuk teh basah di PTP. Nusantara VI Kayu Aro telah berjalan dengan baik. Semua ketentuan yang berkaitan dengan aktivitas perolehan bahan baku mulai dari jadwal pemetikan pucuk teh di lapangan, jadwal pengiriman bahan baku ke pabrik, basis borongan, target bahan baku yang harus diperoleh karyawan, harga premi kelebihan target petik, spesifikasi bahan baku, dan dispensasi yang diberikan kepada karyawan tertentu telah terdokumentasi dengan baik di dalam surat edaran yang 
Jurnal Nominal / Volume I Nomor I / Tahun 2012

dikeluarkan oleh direksi. Namun, perusahaan mengalami permasalahan untuk memenuhi target bahan baku yang telah direncanakan. Perolehan bahan baku teh di akhir tahun jauh di bawah target yang ditetapkan sehingga, berdampak pada penurunan produksi teh kering (Ortodox dan CTC).

\section{b) Kriteria (Criteria)}

1) Standard Operational Procedure (SOP). SOP terlampir di lampiran.

2) Surat Edaran No.06.07/3E/08/2010. Surat edaran ini merupakan penyempurnaan dari standar aktivitas perolehan bahan baku sebelumnya. Surat ini berisikan semua kebijakan dan standar perolehan bahan baku. Kebijakan perolehan bahan baku ditetapkan perusahaan bagi setiap pekerja pemetik yang diatur berdasarkan jenis, kualitas pucuk teh dan cara petik yang dilakukan. Pemetikan manual dengan tangan ditetapkan sebesar $37 \mathrm{~kg} /$ orang, pemetikan menggunakan gunting sebesar 47 $\mathrm{kg} /$ orang, dan pemetikan menggunakan mesin sebesar 200 kg/orang. Surat edaran terlampir di lampiran.

\section{c) Penyebab (Causes)}

Kelancaran perolehan bahan baku merupakan tonggak bagi perusahaan untuk bisa melakukan proses produksi dengan baik, sehingga target produksi yang ditetapkan perusahaan dapat tercapai dengan baik. Sebaliknya, apabila bahan baku tidak terpenuhi sesuai dengan target yang ditetapkan maka kuantitas produk akhir akan mengalami penurunan, sehingga pendapatan perusahaan juga akan menurun dan bisa menyebabkan kerugian. Dalam dekade terakhir terjadi ketidaktercapaian target perolehan bahan baku di PTP. Nusantara VI
Kayu Aro yang disebabkan hal-hal sebagai berikut:

\section{1) Replanting}

Replanting atau dikenal dengan istilah penanaman ulang lahan lama dengan tanaman baru adalah salah satu langkah yang dilakukan oleh perusahaan untuk meningkatkan perolahan bahan baku namun, dalam pelaksanaanya, cara ini membutuhkan waktu yang lama, durasi pembibitan sampai panen perdana membutuhkan waktu selama empat tahun yang selama periode itu bahan baku tidak dihasilkan dari lahan tersebut.

\section{2) Pemangkasan}

Pemangkasan adalah cara yang dilakukan perusahaan untuk memunculkan tunas muda yang lebih bagus dengan memangkas tanaman lama yang sudah kurang produktif dalam menghasilkan pucuk teh. Durasi pemangkasan sampai bisa dipetik ulang membutuhkan waktu selama tiga bulan yang artinya tanaman yang dipangkas tidak menghasilkan pucuk teh selama masa pertumbuhan tersebut sehingga, produksi bahan baku mengalami penurunan.

\section{3) Pengaruh Cuaca dan Hama Tanaman}

Penurunan kuantitas bahan baku juga di sebabkan oleh pengaruh cuaca dan gangguan hama tanaman teh. Curah hujan yang tinggi menyebabkan pucuk teh yang muncul sedikit. Selain itu, gangguan hama tanaman teh juga menyebabkan banyak pucuk teh yang rusak dan tidak dapat digunakan sebagai bahan baku.

\section{4) Usia Tanaman}

Usia tanaman yang sudah sangat tua juga menjadi salah satu penyebab penurunan kuantitas bahan baku. Tanaman yang ditanam sejak tahun 1929 tidak berproduksi secara efektif lagi. 


\section{Jurnal Nominal / Volume I Nomor I / Tahun 2012}

\section{d) Akibat (Effect)}

Ketersediaan bahan baku dalam proses produksi menjadi suatu keharusan yang bertujuan untuk menghasilkan produk akhir sesuai dengan target yang telah ditetapkan. Apabila bahan baku tidak terpenuhi, maka secara otomatis jumlah produk akhir yang diperoleh akan menurun dari target awal. Langkah yang dilakukan oleh PTP. Nusantara VI Kayu Aro seperti replanting dan pemangkasan menyebabkan pohon teh tidak dapat berproduksi dalam rentang waktu yang lama, sehingga perolehan bahan baku akan menurun. Ancaman alami seperti pengaruh cuaca, hama tanaman, dan usia tanaman juga menyebabkan tanaman teh tidak dapat berproduksi secara maksimal yang pada akhirnya akan menurunkan perolehan bahan baku, sehingga produksi teh jadi (Ortodox dan CTC) tidak sesuai dengan target yang direncanakan.

\section{Tingkat Produk Cacat}

\section{a) Kondisi (Condition)}

Upaya pengendalian terjadinya produk cacat yang dilakukan oleh PTP. Nusatara VI Kayu Aro telah berjalan dengan sangat baik dan efektif. Sistematika proses produksi yang jelas dan terorganisir mulai dari penanganan bahan baku (pucuk teh basah), pelayuan, penggulungan, fermentasi, pengeringan, sortasi, hingga pengepakan sudah diatur dengan baik sehingga, produk akhir teh hitam jenis Ortodox dan CTC yang dihasilkan berkualitas tinggi. Selain itu, perawatan mesin secara berkala, petunjuk penggunaan mesin sebelum memproduksi teh yang lengkap, dan petugas produksi yang kompeten membantu perusahaan mengatasi kegagalan produk, pemborosan, dan pengerjaan yang berulang-ulang.

\section{b) Kriteria (Criteria)}

\section{1) Standard Operasional Procedure (SOP) pen-} golahan teh hitam jenis Ortodox dan CTC. SOP ini mengatur proses produksi teh secara sistematis dan jelas. Alur dan ketentuan pengolahan teh yang dimulai dari pemetikan bahan baku dari kebun dan langsung ditimbang dan diangkut ke pabrik yang rentang pemetikan dan pengiriman ke pabrik tidak lebih dari tiga jam, pelayuan bahan baku selama 18 sampai 20 jam, penggulungan, fermentasi dengan temperatur optimum $26,7^{\circ} \mathrm{C}$, pengeringan sampai kadar air yang tersisa hanya 2,5 sampai 3 persen, sortasi berdasarkan jenis dari grade 1 hingga grade 3, pengepakan, hingga dikirim ke bagian pemasaran. SOP terlampir di lampiran.

\section{c) Penyebab (Causes)}

Sistematika dan langkah produksi yang jelas dapat menghindari perusahaan dari pemborosan, pengerjaan yang berulang, dan terjadinya produk cacat. Langkah produksi yang telah diatur dengan baik jelas membuat PTP. Nusantara VI mampu menghindari pemborosan, pengerjaan berulang, dan menghindari terjadinya produk cacat. Meski demikian, produk cacat masih tetap ada namun, jumlah dihasilkan sangat sedikit ( $<1 \%$ dari jumlah produksi bulanan) dan sangat jarang terjadi dan tidak mesti terjadi pada setiap bulan.

\section{d) Akibat (Effect)}

Langkah produksi sistematis yang disusun oleh PTP. Nusantara VI membuat perusahaan mampu menghindari dan meminimalkan terjadinya pemborosan, pengerjaan berulang, dan menghindari terjadinya produk cacat sehingga, teh kering jenis Ortodox dan CTC yang dihasilkan 


\section{Jurnal Nominal / Volume I Nomor I / Tahun 2012}

berkualitas tinggi dan berhasil menembus pasar internasional.

\section{Aktivitas Perawatan Peralatan dan Fasilitas}

\section{Produksi}

\section{a) Kondisi (Condition)}

Aktivitas perawatan peralatan dan fasilitas produksi sudah dijalankan dengan baik. Sebelum beroperasi setiap peralatan dan fasilitas produksi dipastikan kelayakannya dan mesin dalam kondisi siap pakai. Pembersihan peralatan produksi dilakukan setiap hari setelah beroperasi. Perawatan dan pengecekan juga dilakukan secara rutin dan berkala. Perawatan dan pengecekan ulang seluruh peralatan dan fasilitas produksi dilakukan pada awal minggu (Senin) di setiap minggunya. Seluruh petunjuk dan langkah perawatan peralatan dan fasilitas produksi telah terdokumentasi dengan baik dan mudah dipahami oleh petugas maintenance.

\section{b) Kriteria (Criteria)}

Standard Operational Procedure (SOP). Perawatan seluruh peralatan dan fasilitas produksi dilakukan secara rutin dan berkala. Perawatan dan pengecekan ulang seluruh peralatan dan fasilitas produksi dilakukan pada awal minggu (Senin) di setiap minggunya. Sebelum digunakan untuk memproduksi teh kering seluruh mesin dan peralatan produksi diperiksa kelayakannya agar proses open top roller (OTR), press cup roller $(P C R)$, ayakan, rotor vane $(R V)$ berjalan dengan baik. Setelah digunakan untuk kegiatan produksi seluruh mesin dibersihkan kembali. SOP terlampir di lampiran.

\section{c) Penyebab (Causes)}

Kondisi peralatan dan fasilitas produksi siap pakai dan terbebas dari kerusakan sebelum kegiatan produksi disebabkan oleh perawatan peralatan dan fasilitas produksi yang dilakukan setiap hari secara rutin dan berkala. Pembersihan mesin dilakukan setiap hari setelah selesai beroperasi, pengecekan semua peralatan dan fasilitas produksi secara kesluruhan dilaksanakan pada hari senin di setiap minggu. Selain itu, SOP yang mengatur ketentuan perawatan peralatan dan fasilitas produksi telah dilaksanakan dengan baik dan efektif oleh pihak-pihak yang bersangkutan

\section{d) Akibat (Effect)}

Usaha perawatan peralatan dan fasilitas produksi yang dijalankan oleh PTP. Nusantara VI membuat proses produksi berjalan dengan baik dan efektif. Masalah kerusakan peralatan yang menyebabkan terganggunya proses produksi bisa diatasi.

\section{Aktivitas Pengembangan Angkatan Kerja}

\section{a) Kondisi (Condition)}

Pengembangan angkatan kerja di PTP. Nusantara VI Kayu Aro sudah berjalan dengan baik dan efektif. Pimpinan perusahaan telah memberikan pelatihan dan pengembangan kemampuan kerja kepada bawahnnya secara langsung sesuai dengan tanggung jawab yang diembannya. Selain itu, penempatan karyawan secara efektif dan efisien sesuai dengan kemampuan dan potensinya juga sudah dilaksanakan dengan baik. Tanggung jawab dan wewenang pimpinan perusahaan dalam aktivitas pengembangan angkatan kerja telah 


\section{Jurnal Nominal / Volume I Nomor I / Tahun 2012}

terdokumentasi di dalam deskripsi kerja unit/ kebun.

\section{b) Kriteria (Criteria)}

1) Job Description unit/kebun. Pimpinan perusahaan seperti senior manajer, manajer, kepala gudang, dan kepala dinas teknik mempunyai tanggung jawab untuk mengembangkan kemampuan sumber daya manusia, menempatkan karyawan secara efektif dan efisien, dan memberikan pelatihan langsung kepada bawahannya. Job Description unit/kebun terlampir di lampiran.

2) Perjanjian Kerja Bersama (PKB). Perjanjian kerja ini mengatur semua hal yang berkaitan dengan hubungan kerja, jam kerja, hingga pemutusan hubungan kerja yang didalamnya juga diatur pemberian insentif dan penghargaan kepada karyawan yang mempunyai kinerja diatas standar minimal kinerja yang ditetapkan oleh perusahaan. PKB terlampir di lampiran.

\section{c) Penyebab (Causes)}

Penempatan karyawan yang sesuai dengan potensinya dan karyawan yang kompeten disebabkan oleh ketentuan pengembangan angkatan kerja di PTP. Nusantara VI Kayu Aro yang disusun oleh direksi yang tertuang dalam perjanjian kerja bersama dan deskripsi kerja unit/kebun telah dilaksanakan dengan baik oleh pimpinan perusahaan.

\section{d) Akibat (Effect)}

Tugas dan tanggung jawab yang dilaksanakan oleh pimpinan perusahaan untuk memberikan pelatihan kepada karyawan, mengevaluasi dan menilai kinerja karyawan, penempatan karyawan secara efektif dan efisien, dan meningkatkan keterampilan karyawan menghasilkan karyawan yang kompeten dibidangnya dan sesuai dengan posisi yang diembannya.

\section{Aktivitas Pengendalian Kualitas}

\section{a) Kondisi (Condition)}

Ketentuan pengendalian kualitas hingga produk jadi telah terdokumentasi dengan jelas dalam SOP. Bahan baku yang telah dipetik langsung ditimbang dan langsung diangkut ke pabrik yang rentang waktu antara pemetikan dan pengangkutannya tidak boleh lebih dari tiga jam, pengujian contoh bahan baku sebelum proses produksi, pengujian organoleptik untuk produk jadi, hingga proses pembersihan bahan baku yang tercecer dengan cara menyapunya dengan sapu lidi dan tidak boleh digunakan kembali telah dilaksanakan dengan sangat baik dan efektif oleh PTP. Nusantara VI Kayu Aro.

\section{b) Kriteria (Criteria)}

Standard operational procedure (SOP). Standar ini mengatur seluruh aktivitas pengendalian mutu teh, mulai dari penimbangan pucuk di lapangan/kebun, pengangkutan dari kebun ke pabrik yang yang tidak boleh lebih dari tiga jam, perlakuan pucuk teh tercecer dengan cara membersihkannya dengan cara menyapukan menggunakan sapu lidi, hingga pengujian organoleptik pada produk akhir untuk memastikan kualitas teh kering jenis Ortodox dan CTC. SOP terlampir di lampiran. 


\section{Jurnal Nominal / Volume I Nomor I / Tahun 2012}

\section{c) Penyebab (Causes)}

Aktivitas pengendalian kualitas produk dalam sebuah perusahaan merupakan sebuah keharusan bagi perusahaan untuk memastikan bahwa out put yang dihasilkan berkualitas tinggi dan layak digunakan. Pengendalian yang dilakukan oleh PTP. Nusantara VI dari perlakuan bahan baku di lapangan hingga produk jadi bertujuan untuk memastikan bahwa produk yang dihasilkan berkualitas tinggi, layak konsumsi, dan layak edar di masyarakat.

\section{d) Akibat (Effect)}

Pengendalian kualitas yang dilakukan oleh PTP. Nusantara VI Kayu Aro menghasilkan produk teh kering jenis Ortodox dan CTC berkualitas prima, terbebas dari zat berbahaya, dan berhasil menembus pasaran internasional.

\section{Aktivitas Pengepakan dan Penyimpanan Produk Jadi}

\section{a) Kondisi (condition)}

Aktivitas pengepakan dan penyimpanan barang jadi di PTP. Nusantara VI Kayu Aro telah berjalan dengan baik dan efektif. Ketentuan bahan pembungkus dengan standar T2, kandungan kadar air pada bottom pallet sebesar 20 persen, MC maksimal 4,5 persen, pengepakan apabila persediaan peti miring 110 persen dari jumlah shop, pemeriksaan adjustment alat timbang, pengisian bulker hingga seluruh segmen penuh, pemberian identitas/penyablonan bahan pembungkus, paper sack yang ditumpuk dengan posisi silang, penimbangan ulang, hingga pengiriman ke bagian pemasaran telah dil- aksanakan oleh PTP. Nusantara VI dengan baik dan efektif.

\section{b) Kriteria (Criteria)}

Standard Operational Procedure (SOP). Prosedur ini berisikan Ketentuan seperti bahan pembungkus dengan standar T2, kandungan kadar air pada bottom pallet sebesar 20 persen, MC maksimal 4,5 persen, pengepakan apabila persediaan peti miring 110 persen dari jumlah shop, pemeriksaan adjustment alat timbang, pengisian bulker hingga seluruh segmen penuh, pemberian identitas/penyablonan bahan pembungkus, paper sack yang ditumpuk dengan posisi silang, penimbangan ulang, hingga pengiriman ke bagian pemasaran. SOP terlampir di lampiran.

\section{c) Penyebab (Causes)}

Langkah pengepakan dan penyimpanan barang yang dilakukan oleh PTP. Nusantara VI Kayu Aro bertujuan untuk menjamin kualitas produk akhir teh hitam jenis Ortodox dan CTC tetap dalam keadaan baik dan tidak mengalami kerusakan maupun penurunan kualitas hingga dikirimkan kepasar sampai diterima oleh konsumen di dalam maupun di luar negeri.

\section{d) Akibat (Effect)}

Standar dan aturan aktivitas pengepakan dan penyimpanan barang jadi yang ditetapkan PTP. Nusantara VI Kayu Aro membuat produk akhir teh kering jenis Ortodox dan CTC selalu dalam keadaan prima dan tidak mengalami kerusakan maupun penurunan kualitas selama proses pengepakan awal, penyimpanan, hingga didistribusikan ke bagian pemasaran dan akhirnya sampai di tan- 


\section{Jurnal Nominal / Volume I Nomor I / Tahun 2012}

gan konsumen dalam negeri maupun konsumen luar negeri. Standar pengepakan yang menggunakan paper sack impor berkualitas tinggi yang kedap udara yang didatangkan dari Australia juga berhasil menjaga aroma, kualitas, dan keharuman teh.

Adapun hasil audit atas fungsi produksi di PTP. Nusantara VI Kayu Aro adalah sebagai berikut:

\section{Jadwal Induk Produksi}

Jadwal induk produksi di setiap unit bisnis telah terintegrasi dan terdokumentasi dengan baik. Jadwal pemetikan bahan baku dilapangan, pengiriman bahan baku ke pabrik, perawatan perlatan dan fasilitas produksi, hingga pengiriman barang jadi ke bagian pemasaran yang oleh PTP. Nusantara VI Kayu Aro telah dijalankan sesuai standar yang ditetapkan. Namun demikian, bagian pengolahan mengalami permasalahan berupa kinerja mesin di bawah kinerja maksimal yang disebabkan oleh keterbatasan perolehan bahan baku sehingga, mesin sering menganggur pada saat jam kerja.

\section{Aktivitas Perolehan Bahan Baku}

Seluruh ketentuan yang berkaitan dengan aktivitas perolehan bahan baku seperti jadwal pemetikan bahan baku di lapangan dan rentang waktu pemetikan dengan pengiriman bahan baku ke pabrik tidak lebih dari tiga jam, basis borongan yang dengan ketentuan minimum yang harus dicapai karyawan, harga premi kelebihan petik, spesifikasi bahan baku yang bisa diterima untuk diolah, dan dispensasi yang diberikan kepada karyawan tertentu telah dijalankan dengan baik oleh manajemen PTP. Nusantara VI Kayu Aro. Namun, perusahaan masih mengala- mi kendala untuk mencapai kuantitas bahan baku yang diargetkan. Masalah pencapaian bahan baku di bawah target disebabkan oleh bebarapa faktor seperti, Replanting, pemangkasan, pengaruh cuaca dan hama tanaman, hingga usia tanaman yang sudah sangat tua dan tidak bisa memproduksi bahan baku secara maksimal. Seluruh masalah tersebut menyebabkan produksi bahan baku terganggu dan hasil yang diperoleh jauh di bawah standar.

\section{Tingkat Produk Cacat}

Sistematika proses produksi yang jelas dan terorganisir mulai dari penanganan bahan baku, pelayuan, penggulungan, fermentasi, pengeringan, sortasi, hingga pengepakan sudah diatur dengan baik. Sehingga produk akhir teh hitam jenis Ortodox dan CTC yang dihasilkan berkualitas tinggi. Selain itu, perawatan mesin secara berkala, petunjuk penggunaan mesin sebelum memproduksi teh yang lengkap, dan petugas produksi yang kompeten telah terlaksana dengan baik.

4. Aktivitas Perawatan Peralatan dan Fasilitas Produksi

Sebelum beroperasi setiap peralatan dan fasilitas produksi dipastikan kelayakannya dan mesin dalam kondisi siap pakai. Pembersihan peralatan produksi dilakukan setiap hari setelah beroperasi. Perawatan dan pengecekan juga dilakukan secara rutin dan berkala. Perawatan dan pengecekan ulang seluruh peralatan dan fasilitas produksi dilakukan pada awal minggu (Senin) di setiap minggunya. Seluruh petunjuk dan langkah perawatan peralatan dan fasilitas produksi telah terdokumentasi dengan baik dan 


\section{Jurnal Nominal / Volume I Nomor I / Tahun 2012}

mudah dipahami oleh petugas maintenance. Seluruh ketentuan perawatan peralatan dan fasilitas produksi tersebut telah dijalankan oleh PTP. Nusantara VI Kayu Aro.

\section{Aktivitas Pengembangan Angkatan Kerja}

Aktivitas Pengembangan angkatan kerja telah diatur dan terdokumentasi dalam deskripsi kerja unit/kebun dimana pimpinan perusahaan bertanggung jawab terhadap penempatan karyawan secara efektif dan efisien, pemberian pelatihan kepada bawahan, dan peningkatan kemampuan kinerja bawahan. Pimpinan perusahaan telah memberikan pelatihan dan pengembangan kemampuan kerja kepada bawahnnya secara langsung sesuai dengan tanggung jawab yang diembannya. Selain itu, penempatan karyawan secara efektif dan efisien sesuai dengan kemampuan dan potensinya sudah dilaksanakan dengan baik.

\section{Aktivitas Pengendalian Kualitas}

Standar pengendalian kualitas yang dimulai dari pengendalian bahan baku, pengujian contoh bahan baku sebelum diproduksi, pengujian organopleptik untuk produk jadi, hingga penanganan bahan baku yang tercecer dengan cara menyapunya dengan sapu lidi telah dilaksanakan dengan baik oleh perusahaan. Kesemua standar pengendalian kualitas telah terdokumentasi dalam SOP.

\section{Aktivitas Pengepakan dan Penyimpanan Produk} Jadi

Ketentuan pengepakan dan penyimpanan barang jadi seperti pembungkus dengan standar T2, kandungan kadar air pada bottom pallet sebesar 20 persen, MC maksimal 4,5 persen, pengepa- kan apabila persediaan peti miring 110 persen dari jumlah shop, pemeriksaan adjustment alat timbang, pengisian bulker hingga seluruh segmen penuh, pemberian identitas/penyablonan bahan pembungkus, paper sack yang ditumpuk dengan posisi silang, penimbangan ulang, hingga pengiriman ke bagian pemasaran telah dilaksanakan dengan baik oleh PTP. Nusantara VI.

8. Pencapaian Efektivitas Aktivitas Fungsi Produksi

Pencapaian efektivitas yang tinggi pada aktivitas fungsi produksi dalam sebuah perusahaan menggambarkan keberhasilan perusahaan dalam mengelola kegiatan produksinya. Semakin tinggi efektivitas pada aktivitas fungsi produksi yang dicapai maka semakin tinggi pula kesuksesan pengelolaan yang dicapai perusahaan dan sebaliknya semakin rendah pencapaian efektivitas maka akan kelihatan bahwa terdapat masalah dalam pengelolaan aktivitas fungsi produksi tersebut. Pengelolaan aktivitas fungsi produksi di PTP. Nusantara VI Kayu Aro secara keseluruhan telah berjalan secara efektif. Pengelolaan jadwal induk produksi, perolehan bahan baku, tingkat produk cacat, perawatan peralatan dan fasilitas produksi, pengembangan angkatan kerja, pengendalian kualitas, hingga pengepakan dan penyimpanan barang jadi telah dijalankan sesuai dengan ketentuan yang telah ditetapkan. Namun demikian, perusahaan masih mengalami kendala dalam memenuhi target kebutuhan bahan baku yang ditetapkan. Masalah pemenuhan target kebutuhan bahan baku disebabkan oleh beberapa hal diantaranya adalah replanting, pemangkasan, pengaruh cuaca dan hama tanaman, dan usia tanaman teh yang 


\section{Jurnal Nominal / Volume I Nomor I / Tahun 2012}

sudah tua yang tidak produktif lagi dalam menghasilkan pucuk teh yang digunakan sebagai bahan baku. Masalah ini juga berpengaruh pada kinerja bagian pengolahan, mesin pengolahan bekerja di bawah kinerja maksimal.

\section{Penutup}

\section{1) Kesimpulan}

Berdasarkan telaah dan pembahasan terhadap penelitian tentang audit manajemen atas fungsi produksi di PTP. Nusantara VI Kayu Aro Kerinci, Jambi, maka penelitian ini dapat disimpulkan sebagai berikut:

\section{Aktivitas Fungsi Produksi}

a. Jadwal Induk Produksi

Jadwal induk produksi antar unit bisnis di PTP. Nusantara VI Kayu Aro telah terintegrasi dengan baik dan efektif. Standarstandar dan jadwal-jadwal kegiatan produksi di setiap unit bisnis telah terdokumentasi dan dilaksanakan dengan baik. Namun, masih terdapat permasalahan seperti kinerja mesin pengolahan di bawah kinerja maksimal dikarenakan ketidaktercapaian perolehan bahan ba$\mathrm{ku}$.

\section{b. Aktivitas Perolehan Bahan Baku}

Ketentuan perolehan bahan baku telah terdokumentasi dengan jelas dan pelaksanaanya pun telah dijalankan dengan baik. Namun, perusahaan masih mengalami permasalahan dalam mencapai target kuantitas perolehan bahan baku, permasalahan tersebut disebabkan oleh kebijakan perusahaan untuk melakukan penanaman ulang pohon teh atau replanting, pemangkasan pohon teh yang kurang produktif, pengaruh cuaca dan hama tanaman, dan pengaruh usia tanaman teh yang sudah sangat tua.

c. Tingkat Produk Cacat

Upaya memininalkan dan menghindari terjadinya produk cacat telah dijalankan dengan baik dan efektif oleh PTP. Nusantara VI Kayu Aro. Ketentuan dan sistematika proses produksi telah dijalankan dengan baik dan efektif sehingga pemborosan, pengerjaan berulang, dan kemungkinan terjadinya produk cacat bisa diatasi.

d. Aktivitas Perawatan Peralatan dan Fasilitas Produksi

Aktivitas perawatan peralatan dan fasilitas produksi telah berjalan secara efektif. Perawatan berkala, pengecekan mesin sebelum beroperasi, pembersihan mesin setelah digunakan, pengecekan seluruh peralatan dan dan fasilitas produksi di setiap awal minggu telah dilaksanakan dengan baik.

\section{e. Aktivitas Pengembangan Angkatan Kerja}

Tugas dan tanggung jawab pimpinan perusahaan seperti senior manajer, manajer, kepala pabrik, kepala gudang, dan kepala dinas teknik untuk meningkatkan kemampuan kinerja, pengetahuan, menempatkan karyawan secara efektif dan efisien, pemberian pelatihan kepada bawahannya telah dilaksanakan dengan baik dan telah terdokumentasi dalam deskripsi kerja unit/kebun.

\section{f. Aktivitas Pengendalian Kualitas}

Standard Operational Procedure (SOP) yang lengkap dan ketat yang ditetapkan oleh perusahaan telah dilaksanakan dengan baik dan efektif. Ketentuan perusahaan mengenai bahan baku yang harus segera dikirim ke pabrik dalam rentang waktu maksimal tiga jam, pengujian contoh bahan baku yang layak diproduksi, hingga proses penanganan bahan baku yang tercecer 


\section{Jurnal Nominal / Volume I Nomor I / Tahun 2012}

telah dilaksanakan secara baik.

g. Aktivitas Pengepakan dan Penyimpanan Barang Jadi

Ketentuan pengepakan yang ditetapkan perusahaan seperti standar pembungkus yang harus berstandar T2, kandungan air pada bottom pallet, penimbangan ulang, penyablonan dan identitas pada pembungkus, penumpukan paper sack secara menyilang, hingga pengiriman ke bagian pemasaran telah dilaksanakan dengan baik dan efektif.

h) Pencapaian Efektivitas Aktivitas Fungsi Produksi

Pengelolaan aktivitas fungsi produksi di PTP. Nusantara VI Kayu Aro secara keseluruhan telah berjalan secara efektif. Namun demikian, perusahaan masih mengalami kendala dalam memenuhi target kebutuhan bahan baku yang ditetapkan. Masalah pemenuhan target kebutuhan bahan baku disebabkan oleh beberapa hal diantaranya adalah replanting, pemangkasan, pengaruh cuaca dan hama tanaman, dan usia tanaman teh yang sudah tua yang tidak produktif lagi dalam menghasilkan pucuk teh yang digunakan sebagai bahan baku.

\section{2) Keterbatasan Penelitian}

Adapun beberapa keterbatasan dalam penelitian ini adalah sebagai berikut:

a. Penelitian ini dilakukan hanya pada bulan Februari sampai dengan bulan Maret 2012. Hasil penelitian ini tidak dapat dijadikan bahan acuan penilaian kinerja dan pencapaian efektivitas fungsi produksi pada PTP. Nusantara VI Kayu Aro untuk jangka waktu panjang dikarenakan waktu penelitian yang relatif singkat.

b. Skripsi ini masih jauh dari sempurna, terdapat berbagai kekurangan baik dalam tata cara penulisan, pelaporan hasil penelitian, dan kekurangan lainnya. Hal ini disebabkan oleh keterbatasan pengetahuan dan pengalaman peneliti dalam bidang audit manajemen.

\section{3) Saran}

Bagi peneliti selanjutnya yang akan melakukan penelitian di bidang yang sama audit manajemen atas fungsi produksi sebaiknya melakukan observasi awal lebih dari sekali hal ini bertujuan untuk mengetahui gambaran jelas permasalahan yang ada di perusahaan tersebut. Selain itu, untuk memperoleh kesimpulan yang lebih sempurna sebaiknya penelitian dilakukan dalam rentang waktu yang lebih lama.

\section{E. DAFTAR PUSTAKA}

Abdul Halim.(2003). Auditing. Yogyakarta: Akademi Manajemen Perusahaan YKPN.

Amin Widjaya Tunggal. (2000). Manajemen Audit Suatu Pengantar. Jakarta : PT. Rineka Cipta.

Arens, Alvin A., dan Loebbecke, James K. (1995). Auditing: Suatu Pendekatan Terpadu. Jakarta: Erlangga.

Arman Hakim Nasution dan Yudha Prasetyawan. (2008). Perencanaan Pengendalian Produksi. Yogyakarta: Graha Ilmu.

Bayangkara, IBK. (2008). Management Audit: Audit Manajemen Prosedur dan Implementasi. Jakarta : Salemba Empat. 
Jurnal Nominal / Volume I Nomor I / Tahun 2012

Cahyati Widasari. (2009). Audit Manajemen atas Fungsi Produksi pada Perusahaan Manggala Glove Kasihan Bantul. Skripsi. Universitas Negeri Yogyakarta FISE.

Haryono Yusuf. (2001). Auditing. Yogyakarta: Bagian Penerbitan Sekolah Tinggi Ilmu Ekonomi YKPN.

Hendra Kusuma. (2004). Manajemen Produksi Perencanaan dan Pengendalian Produksi. Yogyakarta: Andi Offset.

Indra Bastian. (2007). Audit Sektor Publik. Jakarta: Salemba Empat.

Indriyo Gitosudarmo. (2007). Manajemen Operasi. Yogyakarta : BPFE.

Jay Heizer Dan Barry Render. (2005). Operation Management: Manajemen Produksi. Jakarta: Salemba Empat.

Murdifin Haming dan Mahafud Nurjamuddin. (2007). Manajemen Produksi Modern Operasi Faktur dan Jasa. Jakarta: Bumi Aksara.
Nanang Kurniawan. (2009). Audit Manajemen Untuk Menilai Efektivitas dan Efisiensi atas Fungsi Produksi pada Perusahaan Batik Plentong Yogyakarta. Skripsi. Universitas Negeri Yogyakarta FISE.

Niki Purwitasari. (2010). Audit Operasional atas Fungsi Produksi pada PT. Perkasa Primarindo. Diakses dari http:// papers.gunadarma.ac.id/index.php/economy/ article/viewFile/882/884, pada tanggal 13 September 2011.

PTPN 6. (2012). Teh Hitam. Diakses dari http:// ptpn6.com, pada tanggal 10 Februari 2012.

Sugiyono. (2001). Metode Penelitian Administrasi. Bandung: Alfabeta.

Sukanto Reksohadiprodjo. (2003). Manajemen Produksi dan Operasi. Yogyakarta: BPFE.

Boyton, William C., \& Johnson, Raymond N. (2006). Modern Auditing: Assurance Services and the Integrity of Financial Reporting. United State of America: John wiley \& Sons, Inc. 